\title{
Wastewater Treatment Processes: Part I
}

\author{
George Z. Kyzas 1,*(D) and Kostas A. Matis ${ }^{2, *(D)}$ \\ 1 Department of Chemistry, International Hellenic University, GR-654 04 Kavala, Greece \\ 2 Department of Chemistry, Aristotle University, GR-541 24 Thesslaoniki, Greece \\ * Correspondence: kyzas@chem.ihu.gr (G.Z.K.); kamatis@chem.auth.gr (K.A.M.); \\ Tel.: +30-25-1046-2218 (G.Z.K.)
}

Received: 9 March 2020; Accepted: 9 March 2020; Published: 12 March 2020

check for updates

Cheap and plentiful, water was for centuries a manufacturing tool that industry took for granted. However, population growth, globalization, and climate change are shepherding in a new water-constrained era. The food-chain pyramid may receive contaminants of either surface water or ground water around industrial and residential communities (e.g., metals, pesticides, pharmaceuticals, etc.) through man's activities and on top of the pyramid, man (perhaps) receives pre-concentrated toxicity. A common given example constitutes areas such as Bangladesh, where many people consumed drinking water with arsenic concentrations-exceeding the guideline values of the World Health Organization (WHO).

A class of pollutants, in particular, that can cause carcinogenetic problems is dyes. Recently, adsorption has been widely applied on wastewater decontamination, because of its removal efficiency from dilute solutions; cellulose has been utilized as an adsorbent component due to its unique properties. Moreover, activated carbons have been among the effective adsorbents because of their excellent sorption capacity; their use has been often prohibited mainly due to their relatively high cost, low selectivity and regeneration problems. In recent years, the trend of researchers has been also to use some low-cost materials as adsorbent materials. For example, the idea was applied to leachate, a complex liquid that is often produced from landfills and it contains hazardous substances that may endanger the surrounding environment, if ineffectively treated. Among the other adsorbents, metal organic frameworks have been also developed due to their larger porosity and larger specific surface area.

Wastewater treatment plants focus, among others, on sustainability issues through the recovery of energy and nutrients from wastewater. Aeration is one of the most energy-consuming processes in the conventional activated sludge systems of wastewater treatment technology. Exploration and production of oil and gas generates considerable high-salinity wastewater discharged from offshore oil rigs; as a first step, physical treatment methods and electrolysis were applied. The application of membranes downstream is of interest, including to hospital wastewaters. The membrane bioreactor is a technology that has recently been applied to wastewater treatment for the purpose of reusing treated water and improving the sustainability of the water environment. Saline water treatment (i.e., in the Mediterranean area small islands) has become increasingly important for drinking water supplies.

The knowledge of chemistry can help in different separation processes, as evidenced by various examples; a wide variety of heavy metal bearing waste streams require treatment, so due to their solubilities and mobilities, toxic metals could cause significant damage to the environment. The effect of hydrophobic/hydrophilic organic ligands on sorption and sedimentation of - for instance-zinc oxide nanoparticles has been investigated. Basic chemistry has been (and can be) used to explore well flotation - the possibility if it works in a given system, expectation of the result/recovery, mechanism of this separation process itself including relative explanations; noting, of course, that without flotation, many common metals and inorganic raw materials would be exceedingly scarce and costly-because the high-grade ores that could be processed by simple physical and mechanical methods have long 
since been used up. Concluding, good, clean water just cannot be replaced-and it is becoming harder to come by. Typical processes that are investigated and applied to wastewater treatment include thes following: Biological, adsorption, flocculation, oxidation, membranes, filtration, and so on, including the nanotechnological.

This Special Issue on "Wastewater Treatment Processes" sought (and finally we believe succeeded) to present hereby high-quality works and topics (not only those) focusing on the latest novel wastewater processes. The first part of this Special Issue consists of 46 works ( 41 research articles; 3 review papers, 1 teaching note; 1 project report) from distinguished authors worldwide [1-46]. Among them, there are several processes of wastewater treatment including major techniques as adsorption $[2,3,6,7,14,15,20$, 25,31,36,38,40,45], membranes/filtration [8,35,37,43,44], floation/flocculation/coagulation [11,18,26,46], ultrasonication/ozonation/aeriation [13,23], electroprocesses [1,22,33], photocatalysis [34], etc. Many authors, whom we-as editors - thank very much, from various countries, contributed marvellously to this first part of the present Special Issue. All the aforementioned topics and much more were explored in detail. Certainly, the field of wastewater treatment and its processes is vast; the present hopefully adds one more, useful contribution.

Author Contributions: Writing—original draft preparation and supervision, writing-review and editing, supervision, K.A.M. and G.Z.K. All authors have read and agreed to the published version of the manuscript.

Acknowledgments: In this section you can acknowledge any support given which is not covered by the author contribution or funding sections. This may include administrative and technical support, or donations in kind (e.g., materials used for experiments).

Conflicts of Interest: The authors declare no conflict of interest.

\section{References}

1. A Al-Raad, A.; Hanafiah, M.M.; Naje, A.S.; Ajeel, M.A.; O Basheer, A.; Ali Aljayashi, T.; Ekhwan Toriman, M. Treatment of Saline Water Using Electrocoagulation with Combined Electrical Connection of Electrodes. Processes 2019, 7, 242. [CrossRef]

2. Ali, I.H.; Al Mesfer, M.K.; Khan, M.I.; Danish, M.; Alghamdi, M.M. Exploring Adsorption Process of Lead (II) and Chromium (VI) Ions from Aqueous Solutions on Acid Activated Carbon Prepared from Juniperus procera Leaves. Processes 2019, 7, 217. [CrossRef]

3. Amro, A.N.; Abhary, M.K.; Shaikh, M.M.; Ali, S. Removal of Lead and Cadmium Ions from Aqueous Solution by Adsorption on a Low-Cost Phragmites Biomass. Processes 2019, 7, 406. [CrossRef]

4. Bambaranda, B.V.A.S.; Sasaki, N.; Chirapart, A.; Salin, K.R.; Tsusaka, T.W. Optimization of Macroalgal Density and Salinity for Nutrient Removal by Caulerpa lentillifera from Aquaculture Effluent. Processes 2019, 7, 303. [CrossRef]

5. Bambaranda, B.V.A.S.; Tsusaka, T.W.; Chirapart, A.; Salin, K.R.; Sasaki, N. Capacity of Caulerpa lentillifera in the Removal of Fish Culture Effluent in a Recirculating Aquaculture System. Processes 2019, 7, 440. [CrossRef]

6. Banch, T.J.H.; Hanafiah, M.M.; Alkarkhi, A.F.M.; Amr, S.S.A.; Nizam, N.U.M. Evaluation of Different Treatment Processes for Landfill Leachate Using Low-Cost Agro-Industrial Materials. Processes 2020, 8, 111. [CrossRef]

7. Bian, Y.; Xiong, N.; Zhu, G. Technology for the Remediation of Water Pollution: A Review on the Fabrication of Metal Organic Frameworks. Processes 2018, 6, 122. [CrossRef]

8. Bis, M.; Montusiewicz, A.; Piotrowicz, A.; Łagód, G. Modeling of Wastewater Treatment Processes in Membrane Bioreactors Compared to Conventional Activated Sludge Systems. Processes 2019, 7, 285. [CrossRef]

9. Bogacki, J.; Marcinowski, P.; Majewski, M.; Zawadzki, J.; Sivakumar, S. Alternative Approach to Current EU BAT Recommendation for Coal-Fired Power Plant Flue Gas Desulfurization Wastewater Treatment. Processes 2018, 6, 229. [CrossRef]

10. Che Mid, E.; Dua, V. Fault Detection in Wastewater Treatment Systems Using Multiparametric Programming. Processes 2018, 6, 231. [CrossRef] 
11. Chen, L.; Liu, C.; Sun, Y.; Sun, W.; Xu, Y.; Zheng, H. Synthesis and Characterization of Ampholytic Flocculant CPCTS-g-P (CTA-DMDAAC) and Its Flocculation Properties for Microcystis Aeruginosa Removal. Processes 2018, 6, 54. [CrossRef]

12. Cisterna-Osorio, P.; Lazcano-Castro, V.; Silva-Vasquez, G.; Llanos-Baeza, M.; Fuentes-Ortega, I. Innovative Effluent Capture and Evacuation Device that Increases COD Removal Efficiency in Subsurface Flow Wetlands. Processes 2019, 7, 418. [CrossRef]

13. Drewnowski, J.; Remiszewska-Skwarek, A.; Duda, S.; Łagód, G. Aeration Process in Bioreactors as the Main Energy Consumer in a Wastewater Treatment Plant. Review of Solutions and Methods of Process Optimization. Processes 2019, 7, 311. [CrossRef]

14. Gao, Q.; Wang, L.; Li, Z.; Xie, Y.; He, Q.; Wang, Y. Adsorptive Removal of Pyridine in Simulation Wastewater Using Coke Powder. Processes 2019, 7, 459. [CrossRef]

15. Gómez Aguilar, D.L.; Rodríguez Miranda, J.P.; Esteban Muñoz, J.A.; Betancur, P.J.F. Coffee Pulp: A Sustainable Alternative Removal of Cr (VI) in Wastewaters. Processes 2019, 7, 403. [CrossRef]

16. Guan, Q.; Zhu, G.; Liao, Y.; Xu, J.; Sun, X.; Tian, F.; Xu, J.; Luo, M. Preparation, Characterization, and Sludge Conditioning of Cationic Polyacrylamide Synthesized by a Novel UVA-Initiated System. Processes 2018, 6, 233. [CrossRef]

17. He, F.; Wang, J. Statistical Analysis of Circulating Water Quality Parameters under Variable-Frequency Vertical Electromagnetic Fields. Processes 2018, 6, 182. [CrossRef]

18. Khan, R.; Inam, M.A.; Akram, M.; Uddin, A.; Khan, S.; Yeom, I.T. Effect of Dissolved Organic Matter on Agglomeration and Removal of CuO Nanoparticles by Coagulation. Processes 2019, 7, 455. [CrossRef]

19. Khan, R.; Inam, M.A.; Park, D.R.; Zam Zam, S.; Shin, S.; Khan, S.; Akram, M.; Yeom, I.T. Influence of Organic Ligands on the Colloidal Stability and Removal of ZnO Nanoparticles from Synthetic Waters by Coagulation. Processes 2018, 6, 170. [CrossRef]

20. Kyzas, G.Z.; Christodoulou, E.; Bikiaris, D.N. Basic Dye Removal with Sorption onto Low-Cost Natural Textile Fibers. Processes 2018, 6, 166. [CrossRef]

21. Kyzas, G.Z.; Matis, K.A. Flotation in Water and Wastewater Treatment. Processes 2018, 6, 116. [CrossRef]

22. Łagód, G.; Duda, S.M.; Majerek, D.; Szutt, A.; Dołhańczuk-Śródka, A. Application of Electronic Nose for Evaluation of Wastewater Treatment Process Effects at Full-Scale WWTP. Processes 2019, 7, 251. [CrossRef]

23. Le, T.M.; Vo, P.T.; Do, T.A.; Tran, L.T.; Truong, H.T.; Xuan Le, T.T.; Chen, Y.-H.; Chang, C.-C.; Chang, C.-Y.; Tran, Q.T.; et al. Effect of Assisted Ultrasonication and Ozone Pretreatments on Sludge Characteristics and Yield of Biogas Production. Processes 2019, 7, 743. [CrossRef]

24. Liao, L.; Zhang, P. Preparation and Characterization of Polyaluminum Titanium Silicate and its Performance in the Treatment of Low-Turbidity Water. Processes 2018, 6, 125. [CrossRef]

25. Liu, Y.; Cheng, H.; He, Y. Application and Mechanism of Sludge-Based Activated Carbon for Phenol and Cyanide Removal from Bio-Treated Effluent of Coking Wastewater. Processes 2020, 8, 82. [CrossRef]

26. Ma, J.; Fu, X.; Xia, W.; Fu, K.; Liao, Y. Flocculation of a High-Turbidity Kaolin Suspension Using Hydrophobic Modified Quaternary Ammonium Salt Polyacrylamide. Processes 2019, 7, 108. [CrossRef]

27. Ma, X.; Liu, X.; Xiang, B.; Zhang, W. Effect of Hydraulic Retention Time on Carbon Sequestration during the Two-Stage Anammox Process. Processes 2019, 7, 717. [CrossRef]

28. Mahdi, F.M.; Hunter, T.N.; Holdich, R.G. A Study of Cake Filtration Parameters Using the Constant Rate Process. Processes 2019, 7, 746. [CrossRef]

29. Mustaffa, A.R.; Ku Hamid, K.H.; Musa, M.; Idris, J.; Ramli, R. High Nitrate and Phosphate Ions Reduction in Modified Low Salinity Fresh Water through Microalgae Cultivation. Processes 2019, 7, 129. [CrossRef]

30. Navrozidou, E.; Remmas, N.; Melidis, P.; Karpouzas, D.G.; Tsiamis, G.; Ntougias, S. Biodegradation Potential and Diversity of Diclofenac-degrading Microbiota in an Immobilized Cell Biofilter. Processes 2019, 7, 554. [CrossRef]

31. Basheer, A.O.; Hanafiah, M.M.; Abdulhakim Alsaadi, M.; Al-Douri, Y.; Malek, M.A.; Mohammed Aljumaily, M.; Saadi Fiyadh, S. Synthesis and Characterization of Natural Extracted Precursor Date Palm Fibre-Based Activated Carbon for Aluminum Removal by RSM Optimization. Processes 2019, 7, 249. [CrossRef]

32. Ojo, P.; Ifelebuegu, A.O. The Effects of Aluminium- and Ferric-Based Chemical Phosphorus Removal on Activated Sludge Digestibility and Dewaterability. Processes 2019, 7, 228. [CrossRef] 
33. Peng, H.; Leng, Y.; Cheng, Q.; Shang, Q.; Shu, J.; Guo, J. Efficient Removal of Hexavalent Chromium from Wastewater with Electro-Reduction. Processes 2019, 7, 41. [CrossRef]

34. Saroyan, H.; Kyzas, G.Z.; Deliyanni, E.A. Effective Dye Degradation by Graphene Oxide Supported Manganese Oxide. Processes 2019, 7, 40. [CrossRef]

35. Tran, T.; Nguyen, T.B.; Ho, H.L.; Le, D.A.; Lam, T.D.; Nguyen, D.C.; Hoang, A.T.; Do, T.S.; Hoang, L.; Nguyen, T.D.; et al. Integration of Membrane Bioreactor and Nanofiltration for the Treatment Process of Real Hospital Wastewater in Ho Chi Minh City, Vietnam. Processes 2019, 7, 123. [CrossRef]

36. Trinh, B.-S.; Le, P.T.K.; Werner, D.; Phuong, N.H.; Luu, T.L. Rice Husk Biochars Modified with Magnetized Iron Oxides and Nano Zero Valent Iron for Decolorization of Dyeing Wastewater. Processes 2019, 7, 660. [CrossRef]

37. Xiao, X.; Shi, W.; Ruan, W. Performance and Microbial Community Structure of Anaerobic Membrane Bioreactor for Lipids-Rich Kitchen Waste Slurry Treatment: Mesophilic and Thermophilic Processes. Processes 2019, 7, 879. [CrossRef]

38. Xu, H.; Qin, Q.; Zhang, C.; Ning, K.; Zhao, R.; Wang, P.; Deng, J.; Huang, G. Adsorption of Organic Constituents from Reverse Osmosis Concentrate in Coal Chemical Industry by Coking Coal. Processes 2019, 7, 44. [CrossRef]

39. Yin, H.; Qiu, P.; Qian, Y.; Kong, Z.; Zheng, X.; Tang, Z.; Guo, H. Textile Wastewater Treatment for Water Reuse: A Case Study. Processes 2019, 7,34. [CrossRef]

40. You, Z.; Zhang, L.; Zhang, S.; Sun, Y.; Shah, K.J. Treatment of Oil-Contaminated Water by Modified Polysilicate Aluminum Ferric Sulfate. Processes 2018, 6, 95. [CrossRef]

41. Yulistyorini, A.; Camargo-Valero, M.A.; Sukarni, S.; Suryoputro, N.; Mujiyono, M.; Santoso, H.; Tri Rahayu, E. Performance of Anaerobic Baffled Reactor for Decentralized Wastewater Treatment in Urban Malang, Indonesia. Processes 2019, 7, 184. [CrossRef]

42. Zamora, S.; Sandoval, L.; Marín-Muñíz, J.L.; Fernández-Lambert, G.; Hernández-Orduña, M.G. Impact of Ornamental Vegetation Type and Different Substrate Layers on Pollutant Removal in Constructed Wetland Mesocosms Treating Rural Community Wastewater. Processes 2019, 7, 531. [CrossRef]

43. Zhang, C.; He, J.; Zheng, Z. Modelling Nutrients and Organics Removal by Biological Slow Filtration in Micro-Polluted Water Source Treatment. Processes 2018, 6, 128. [CrossRef]

44. Zhang, W.; Wei, Y.; Jin, Y. Full-Scale Processing by Anaerobic Baffle Reactor, Sequencing Batch Reactor, and Sand Filter for Treating High-Salinity Wastewater from Offshore Oil Rigs. Processes 2018, 6, 256. [CrossRef]

45. Zhang, Y.; Lou, Z.; Wang, C.; Wang, W.; Cai, J. Synthesis of Porous Fe/C Bio-Char Adsorbent for Rhodamine B from Waste Wood: Characterization, Kinetics and Thermodynamics. Processes 2019, 7, 150. [CrossRef]

46. Zhu, Y.; Li, H. A New Method for the Process Division and Effect Evaluation of Coagulation Based on Particle Size Fractal Dimension. Processes 2018, 6, 237. [CrossRef]

(C) 2020 by the authors. Licensee MDPI, Basel, Switzerland. This article is an open access article distributed under the terms and conditions of the Creative Commons Attribution (CC BY) license (http://creativecommons.org/licenses/by/4.0/). 